\title{
Sorption of cadmium ions from saline waters onto Fe(III)-zeolite
}

\author{
Aysha Ali Ahribesh ${ }^{1}$, Slavica Lazarević ${ }^{1}$, Branislav Potkonjak ${ }^{2}$, Andjelika Bjelajac ${ }^{3}$, Djordje Janaćković ${ }^{1}$, \\ Rada Petrović ${ }^{1}$ \\ ${ }^{1}$ Faculty of Technology and Metallurgy, University of Belgrade, Belgrade, Serbia \\ ${ }^{2}$ Institute of Chemistry, Technology and Metallurgy, University of Belgrade, Belgrade, Serbia \\ ${ }^{3}$ Innovation center of the Faculty of Technology and Metallurgy, University of Belgrade, Belgrade, Serbia
}

\begin{abstract}
The sorption of $\mathrm{Cd}^{2+}$ from natural seawater, artificial seawater, distilled water and $\mathrm{NaCl}$ solution of the same ionic strength as the seawater onto zeolite modified by iron(III) oxide (Fe(III)-zeolite) was investigated. The sorption was found to be time, concentration and pH dependent. The sorption capacity at the initial pH 7 decreased in the following order: distilled water $>\mathrm{NaCl}$ solution $>$ artificial seawater > natural seawater. The isotherm study showed that Langmuir isotherm model could be adequately applied for the sorption in distilled water, indicating the homogeneous monolayer coverage at Fe(III)-zeolite surface, while the Freundlich isotherm model showed a better fit than the Langmuir model of the sorption data in saline waters, indicating multilayer heterogeneous coverage at the sorbent surface. The values of Freundlich parameter $n$ suggested that the sorption was a favorable process and bonds between $\mathrm{Cd}^{2+}$ and $\mathrm{Fe}(\mathrm{III})$-zeolite surface were stronger in $\mathrm{NaCl}$ solution than in natural and artificial seawater. Kinetics analysis showed that the mechanism of $\mathrm{Cd}^{2+}$ sorption from natural seawater differed from the sorption mechanism out of distilled water, $\mathrm{NaCl}$ solution and artificial seawater. The intra-particle diffusion kinetic model indicated that both boundary layer diffusion and intra-particle diffusion influenced the rate of sorption.
\end{abstract}

Keywords: sorption, cadmium ions, Fe(III)-zeolite, seawater, modeling.

SCIENTIFIC PAPER

UDC 66.081:546.48:551.464

Hem. Ind. 69 (3) 253-260 (2015)

doi: 10.2298/HEMIND140122038A

Available online at the Journal website: http://www.ache.org.rs/HI/

Cadmium is one of the most toxic heavy metals. It tends to accumulate in the body and it has varying degrees of toxicity. Cadmium causes serious diseases such as renal damage, anemia, hypertension, cancer, and kidney failure [1,2]. According to the World Health Organization (WHO) the maximum concentration of cadmium in drinking water should be $0.003 \mathrm{mg} / \mathrm{L}$ [3].

The common sources of cadmium in natural waters are soil and air pollution due to the several industrial applications such as cadmium plating and production of Cd-Ni batteries, copper alloys, paints, plastics, phosphates, ferilizers, and pigments $[3,4]$.

There are various technologies for the removal of cadmium and other heavy metals from water systems: chemical precipitation, ion exchange, sorption, membrane processing, electrochemical treatment, etc. $[5,6]$. Among these procedures, the sorption is considered as one of the most attractive and powerful technique for heavy metals removal from solutions at low concentrations. By proper selection of the sorbent, the sorption can be a simple, environmental friendly and low cost operation of high efficiency $[7,8]$. A variety of sorbents, including clay minerals, zeolites, agricultural waste bio-

Correspondence: R. Petrović, Faculty of Technology and Metallurgy, University of Belgrade, Karnegijeva 4, Belgrade, Serbia.

E-mail: radaab@tmf.bg.ac.rs

Paper received: 22 January, 2014

Paper accepted: 16 April, 2014 mass, biopolymers, metal oxides, different industrial by-products, microorganisms, and activated carbon have been used for cadmium removal [8].

Zeolites have been extensively used as sorbents for heavy metals because they have great affinity for divalent metal ions [9]. The sorption capacity and selectivity of zeolite to heavy metal ions can be further improved by various modifications. It was shown that zeolites modified by oxides or hydroxides of trivalent iron had significantly higher affinity for $\mathrm{Zn}^{2+}, \mathrm{Cu}^{2+}, \mathrm{Mn}^{2+}, \mathrm{Pb}^{2+}$ and $\mathrm{Cd}^{2+}$, compared to the unmodified zeolite [10-14]. Iron(III) could be present in zeolite in different forms [15]: a) in framework positions (isomorphously substituted), b) in cationic positions in the zeolite channels, c) as binuclear or oligonuclear iron complexes in the extra-framework positions, d) as iron oxide $\mathrm{FeO}_{x}$ nanoparticles and e) as large iron oxide particles $\left(\mathrm{Fe}_{2} \mathrm{O}_{3}\right)$ located on the surface of the zeolite crystals. Much higher capacity of the iron(III)-modified zeolite for $\mathrm{Pb}^{2+}$, $\mathrm{Cd}^{2+}$ and $\mathrm{Zn}^{2+}$ in comparison to parent zeolite was explained [14] by: higher specific sorption resulting from the new functional groups on the surface; ion exchange due to the presence of easily exchangeable ions; the hydroxide precipitation caused by the higher point of zero charge.

The purpose of this work was to investigate the sorption of cadmium ions from natural seawater and various aqueous solutions on zeolite, modified by 
iron(III) oxide. Cadmium ion solutions of different concentrations in natural and artificial seawater were used for the experiments. For comparison, the sorption of cadmium from solutions prepared with distilled water was studied, as well as using $\mathrm{NaCl}$ solution of the same ionic strength as the seawater. The influence of the initial $\mathrm{pH}\left(\mathrm{pH}_{\mathrm{i}}\right)$ on the sorption from different water systems was evaluated. The sorption capacities of the sorbent at $\mathrm{pH}_{\mathrm{i}} 7$ were determined based on sorption isotherms, and experimental results were analyzed using theoretical models of sorption isotherms. The results of sorption kinetics of cadmium from different water systems were processed using the kinetic models.

\section{EXPERIMENTAL}

\section{Materials}

\section{Sorbent}

Zeolite modified by iron(III) oxide (Fe(III)-zeolite) was synthesized according to previously published method [10-14]. A natural zeolite from the Slanci locality, Serbia, was used as a starting material. The natural zeolite contained clinoptilolite, as a dominant phase, with lower contents of quartz and feldspar. The modified zeolite was prepared by adding, under stirring, of $180 \mathrm{~cm}^{3}$ of $5 \mathrm{M} \mathrm{KOH}$ solution to a suspension of $20.0 \mathrm{~g}$ of the natural zeolite and $100 \mathrm{~cm}^{3}$ of a freshly prepared $1 \mathrm{M} \mathrm{FeCl}_{3}$ solution. The suspension was diluted by distilled water up to $2 \mathrm{dm}^{3}$ and held in a closed polyethylene flask at $70{ }^{\circ} \mathrm{C}$ for $60 \mathrm{~h}$. Then, the reaction vessel was removed from the oven, and the red precipitate was centrifuged and washed until the negative reaction of $\mathrm{Cl}^{-}$ions occurred and it was finally dried.

XRD analysis showed lower crystallinity of Fe(III)zeolite in comparison to the parent zeolite. In addition, it was shown that Fe(III)-zeolite contained amorphous iron(III) oxides. The modification caused the specific surface area increasing from 18 to $175 \mathrm{~m}^{2} / \mathrm{g}$ and the point of zero charge increasing from $7.5 \pm 0.1$ to $9.3 \pm 0.1$ [14].

\section{Water samples}

The four types of water were used:

1. Distilled water.

2. Natural seawater obtained of the coast of Greece and passed through $2 \mu \mathrm{m}$ filter. The $\mathrm{pH}$ value of natural seawater was about 8 . The analysis of seawater was done by a Metrohm ion chromatography instrument, 861 Advanced Compact IC MSM II. The concentrations of the main ions in the natural seawater are presented in Table 1.

3. Artificial seawater, prepared by dissolving $28.6 \mathrm{~g}$ $\mathrm{NaCl}, 0.65 \mathrm{~g} \mathrm{KCl}, 5.26 \mathrm{~g} \mathrm{MgCl}_{2} .6 \mathrm{H}_{2} \mathrm{O}, 4.77 \mathrm{~g}$ $\mathrm{MgSO}_{4} \cdot 7 \mathrm{H}_{2} \mathrm{O}, 1.16 \mathrm{~g} \mathrm{CaSO}_{4}$ and $0.05 \mathrm{~g} \mathrm{NaBr}$ in $1 \mathrm{dm}^{3}$ of distilled water in order to obtain the composition similar to the composition of the natural seawater.

4. $\mathrm{NaCl}$ solution, prepared by dissolving $40.2 \mathrm{~g} \mathrm{NaCl}$ in $1 \mathrm{dm}^{3}$ of distilled water in order to obtain the solution of the same ionic strength as the seawater.

Table 1. Composition of the natural seawater used in the experiments

\begin{tabular}{lcc}
\hline Ion & $\mathrm{mg} / \mathrm{dm}^{3}$ & $\mathrm{mmol} / \mathrm{dm}^{3}$ \\
\hline $\mathrm{Cl}^{-}$ & 19990 & 564.13 \\
$\mathrm{Na}^{+}$ & 11244 & 488.9 \\
$\mathrm{~K}^{+}$ & 342 & 8.74 \\
$\mathrm{Mg}^{2+}$ & 1099 & 45.22 \\
$\mathrm{Ca}^{2+}$ & 343 & 8.56 \\
$\mathrm{SO}_{4}{ }^{2-}$ & 2679 & 27.91 \\
$\mathrm{Br}^{-}$ & 49.4 & 0.62 \\
\hline
\end{tabular}

\section{Sorbate solution preparation}

The stock solutions of cadmium, containing $100 \mathrm{mg}$ $\mathrm{Cd}^{2+} / \mathrm{dm}^{3}$, were prepared by dissolving $0.1372 \mathrm{~g}$ of $\mathrm{Cd}\left(\mathrm{NO}_{3}\right)_{2} \cdot 4 \mathrm{H}_{2} \mathrm{O}$ in $500 \mathrm{~cm}^{3}$ of each type of water. The solutions of different cadmium concentration ranging from 5 to $75 \mathrm{mg} / \mathrm{dm}^{3}$, were prepared from stock solutions, by dilution.

The $\mathrm{pH}$ of the solutions for the sorption experiments was adjusted by $0.1 \mathrm{M} \mathrm{KOH}$ or $0.1 \mathrm{M} \mathrm{HNO}_{3}$ solution.

\section{Sorption experiments}

The sorption experiments were performed by batch technique at room temperature $\left(25 \pm 1^{\circ} \mathrm{C}\right)$. The general method used for this study is described as follows: 20 $\mathrm{cm}^{3}$ of different cadmium solutions were placed in 50 $\mathrm{cm}^{3}$ reagent bottle, the $\mathrm{pH}$ value was adjusted and then the constant amount of $\mathrm{Fe}(\mathrm{III})$-zeolite $(0.02 \mathrm{~g})$ was added to each bottle, followed by shaking for a given period of time.

The effect of initial $\mathrm{pH}$ value $\left(\mathrm{pH}_{\mathrm{i}}\right)$ on $\mathrm{Cd}^{2+}$ sorption onto $\mathrm{Fe}(\mathrm{III})$-zeolite was investigated with $\mathrm{Cd}^{2+}$ solution of $50 \mathrm{mg} / \mathrm{dm}^{3}$ concentration, by varying $\mathrm{pH}_{\mathrm{i}}$ from 4.0 to 8.0. The suspensions were shaken for $24 \mathrm{~h}$.

The sorption isotherms for $\mathrm{Cd}^{2+}$ sorption out of different types of water onto $\mathrm{Fe}(\mathrm{III})$-zeolite at $\mathrm{pH}_{\mathrm{i}} 7.0 \pm 0.1$ were determined by establishing the equilibration of $\mathrm{Cd}^{2+}$ solution of different concentration and $\mathrm{Fe}$ (III)-zeolite for $24 \mathrm{~h}$.

The kinetics analysis of the sorption was done by using $\mathrm{Cd}^{2+}$ solutions of $100 \mathrm{mg} / \mathrm{dm}^{3}$, at $\mathrm{pH}_{\mathrm{i}} 7.0 \pm 0.1$.

After all the experiments, the sorbent was separated from the solution using filter paper. The final solution $\mathrm{pH}\left(\mathrm{pH}_{\mathrm{f}}\right)$ was measured using a $\mathrm{pH}$ meter (InoLab WTW series $\mathrm{pH} 720$ ). The initial concentrations of $\mathrm{Cd}^{2+}$, as well as the concentrations after the sorption, were 
determined using the atomic absorption spectrometer (AAS) (Perkin Elmer 730).

The equilibrium sorption capacity, $q_{\mathrm{e}}$, was calculated using the equation:

$q_{\mathrm{e}}=\frac{c_{\mathrm{i}}-c_{\mathrm{e}}}{m} V\left(\mathrm{mg} \mathrm{Cd}^{2+} / \mathrm{g} \mathrm{Fe}(\mathrm{III})-\right.$ zeolite $)$

while the quantity of $\mathrm{Cd}^{2+}$ sorbed after the period of time $t\left(q_{\mathrm{t}}\right)$ was calculated according to equation:

$q_{t}=\frac{c_{\mathrm{i}}-c_{t}}{m} V\left(\mathrm{mg} \mathrm{Cd}^{2+} / \mathrm{g} \mathrm{Fe}(\right.$ III)-zeolite $)$

where $V$ is the volume of the solution; $c_{i}$ is the initial $\mathrm{Cd}^{2+}$ concentration, $c_{\mathrm{e}}$ is the equilibrium (residual) $\mathrm{Cd}^{2+}$ concentration; $m$ is the weight of sorbent and $c_{t}$ is the concentration of $\mathrm{Cd}^{2+}$ after period of time $t$.

\section{Models of isotherms}

The Langimur [16] and Freundlich [17] isotherms were applied to the experimental data to study the sorption capacity and to describe the solid-liquid sorption process:

Langmuir model: $q_{\mathrm{e}}=\frac{q_{\mathrm{m}} k_{\mathrm{L}} c_{\mathrm{e}}}{1+k_{\mathrm{L}} c_{\mathrm{e}}}$

Freundlich model: $q_{\mathrm{e}}=k_{\mathrm{F}} c_{\mathrm{e}}^{1 / \mathrm{n}}$

where $q_{\mathrm{e}}$ is the amount of solute sorbed per unit mass of the sorbent at equilibrium ( $\mathrm{mg} / \mathrm{g}) ; c_{\mathrm{e}}$ is the equilibrium concentration of the solute in the bulk solution $\left(\mathrm{mg} / \mathrm{dm}^{3}\right) ; q_{\mathrm{m}}$ is the maximum sorption capacity (monolayer capacity, $\mathrm{mg} / \mathrm{g}$ ); $k_{\mathrm{L}}$ is the Langmuir constant related to the free energy of sorption $\left(\mathrm{dm}^{3} / \mathrm{mg}\right) ; k_{\mathrm{F}}$ is a constant which is an indicator of the sorption capacity $\left((\mathrm{mg} / \mathrm{g})\left(\mathrm{mg} / \mathrm{dm}^{3}\right)^{\mathrm{n}}\right)$; and $n$ is an sorption intensity parameter.

\section{Sorption kinetics}

The pseudo-first order equation [18] and the pseudo-second order equation $[19,20]$ were applied to sorption kinetic data to describe the mechanism of sorption:

Pseudo-first order equation:

$\log \left(q_{\mathrm{e}}-q_{\mathrm{t}}\right)=\log q_{\mathrm{e}}-\frac{k_{1} t}{2.303}$

Pseudo-second order equation:

$\frac{t}{q_{\mathrm{t}}}=\frac{1}{k_{2} q_{\mathrm{e}}^{2}}+\frac{t}{q_{\mathrm{e}}}$

where $q_{\mathrm{e}}$ and $q_{\mathrm{t}}$ are sorption capacity at equilibrium and at time $t$, respectively $(\mathrm{mg} / \mathrm{g}) ; k_{1}$ is the rate constant of pseudo first order model $(1 / \mathrm{min})$; and $k_{2}$ is the rate constant of the pseudo second order model (g/(mg.min)).

In order to assess the nature of the diffusion process in $\mathrm{Cd}^{2+}$ sorption onto $\mathrm{Fe}(\mathrm{III})$-zeolite, the intraparticle diffusion model, proposed by Weber and Morris [21] was used:

$q_{\mathrm{t}}=k_{\mathrm{td}} t^{0.5}+C$

where $k_{\mathrm{td}}\left(\mathrm{mg} /\left(\mathrm{g} \cdot \mathrm{min}^{0.5}\right)\right)$ is the intra-particle diffusion rate constant, and $C(\mathrm{mg} / \mathrm{g})$ is a constant that gives information about thickness of the boundary layer. This model considered the intra-particle diffusion as the rate controlling step when the value of $C$ is close to zero.

\section{RESULTS AND DISCUSSION}

\section{Effect of the initial pH}

The influence of initial $\mathrm{pH}$ value on the sorption capacity of $\mathrm{Fe}(\mathrm{III})$-zeolite for $\mathrm{Cd}^{2+}$ in different types of water is presented in Fig 1 . The final $\mathrm{pH}$ values are indicated in this figure.

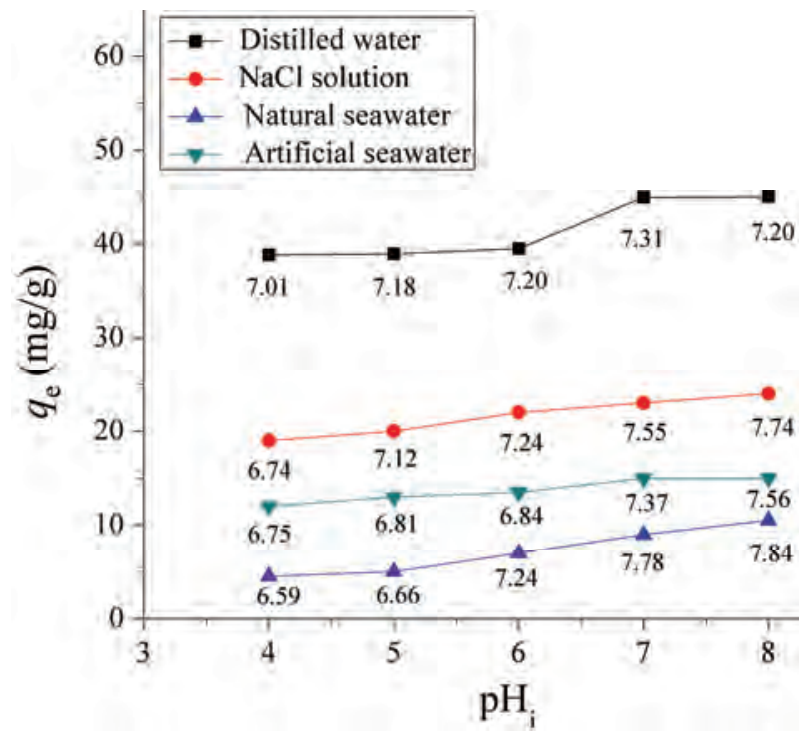

Figure 1. The comparison of the effect of the initial $\mathrm{pH}$ on the sorption capacity of $\mathrm{Fe}$ (III)-zeolite for $\mathrm{Cd}^{2+}$ from different types of water (the numbers in the figure indicate the final $\mathrm{pH}$ values). Concentration of $\mathrm{Cd}(\mathrm{II})$ solution was $50 \mathrm{mg} / \mathrm{dm}^{3}$.

According to Fig. 1, the cadmium sorption efficiency on Fe(III)-zeolite increased when the initial $\mathrm{pH}$ was increased. This appeared because $\mathrm{Fe}(\mathrm{III})$-zeolite was highly selective to $\mathrm{H}_{3} \mathrm{O}^{+}$when the concentration of these ions was high. The values of $\mathrm{pH}_{\mathrm{f}}$, for $\mathrm{pH}_{\mathrm{i}} \leq 7$, indicate that $\mathrm{H}_{3} \mathrm{O}^{+}$associates with the functional groups on the $\mathrm{Fe}$ (III)-zeolite surface. As $\mathrm{pH}_{\mathrm{i}}$ was lower, the negative charge of the surface became lower and the positive charge higher, which decreased the sorption of positively charged cadmium ions. At $\mathrm{pH}_{\mathrm{i}} 8, \mathrm{pH}_{\mathrm{f}}$ values 
were lower than the initial ones, which indicates releasing of $\mathrm{H}_{3} \mathrm{O}^{+}$into the solution because of the surface functional groups dissociation. Thus, the $\mathrm{Cd}^{2+}$ sorption at $\mathrm{pH}_{\mathrm{i}} 8$ was higher than at lower $\mathrm{pH}_{\mathrm{i}}$. These results show that $\mathrm{pH}$ values at which the surface charge was changed from positive to negative and vice versa were lower than $\mathrm{pH}_{\mathrm{PZC}}$ of $\mathrm{Fe}(\mathrm{III})$-zeolite [14], which indicates that the specific sorption is included in the process of $\mathrm{Cd}^{2+}$ sorption, as it was shown in previous investigation for the solutions in distilled water [14].

It should be noted that there was no indication of $\mathrm{Cd}(\mathrm{OH})_{2}$ precipitation during adsorption at higher $\mathrm{pH}$ values. For the $\mathrm{Cd}^{2+}$ concentration of $50 \mathrm{mg} / \mathrm{dm}^{3}$, the saturation for $\mathrm{Cd}(\mathrm{OH})_{2}$ precipitation is at $\mathrm{pH} \approx 8.5$ (according to the value of the solubility product constant of $\left.\mathrm{Cd}(\mathrm{OH})_{2}\right)$. However, in order to start precipitation (nucleation of solid phase from liquid phase), super saturation is necessary [22], which means that $\mathrm{Cd}(\mathrm{OH})_{2}$ precipitation starts at $\mathrm{pH}$ higher than 8.5. If there are some dispersed particles in solution (like the sorbent in $\mathrm{Cd}^{2+}$ solution), a super saturation for nucleation is less than in solution without dispersed particle, but still $\mathrm{pH}$ value for the beginning of precipitation is higher than $\mathrm{pH}$ value for saturation. According to that, it can be said with certainty that there was no $\mathrm{Cd}(\mathrm{OH})_{2}$ precipitation during the experiments.

It can be seen from Fig. 1 that the order of sorption capacity of $\mathrm{Fe}(\mathrm{III})$-zeolite for $\mathrm{Cd}^{2+}$, at all $\mathrm{pHs}$ is: distilled water $>\mathrm{NaCl}$ solution $>$ artificial seawater $>$ natural seawater. Obviously, the ions from saline waters decrease sorption capacity of $\mathrm{Fe}(\mathrm{III})$-zeolite for $\mathrm{Cd}^{2+}$, because those ions compete with $\mathrm{Cd}^{2+}$ for the sorption sites at the surface of the sorbent. The higher-valence ions have more competitive effect than monovalence ions [23], which explains the lower sorption capacity of the sorbent in artificial and natural seawaters than in $\mathrm{NaCl}$ solution: besides $\mathrm{Na}^{+}$, both seawaters contain higher-valence ions, such as $\mathrm{Ca}^{2+}$ and $\mathrm{Mg}^{2+}$. The lowest sorption capacity of the $\mathrm{Fe}(\mathrm{III})$-zeolite in natural seawater can be explained by the presence of some other ions (carbonate and bicarbonate) and organic matter that are not present in artificial seawater.

Further investigations, the determination of sorption isotherms and kinetic analysis, were done at the initial $\mathrm{pH} 7$.

\section{Effect of the initial cadmium ions concentration - sorption isotherms}

Figure 2 shows the sorption isotherms for $\mathrm{Cd}^{2+}$ on $\mathrm{Fe}(\mathrm{III})$-zeolite from different types of water. The equilibrium concentration and the uptake of $\mathrm{Cd}^{2+}$ increase as the initial $\mathrm{Cd}^{2+}$ concentration increases. This appeared since at lower initial concentration the ratio of the initial number of metal ions to the number of available surface sites of sorbent is low. With the increase in the initial $\mathrm{Cd}^{2+}$ concentration, more $\mathrm{Cd}^{2+}$ were left in the solution due to the saturation of the binding sites.

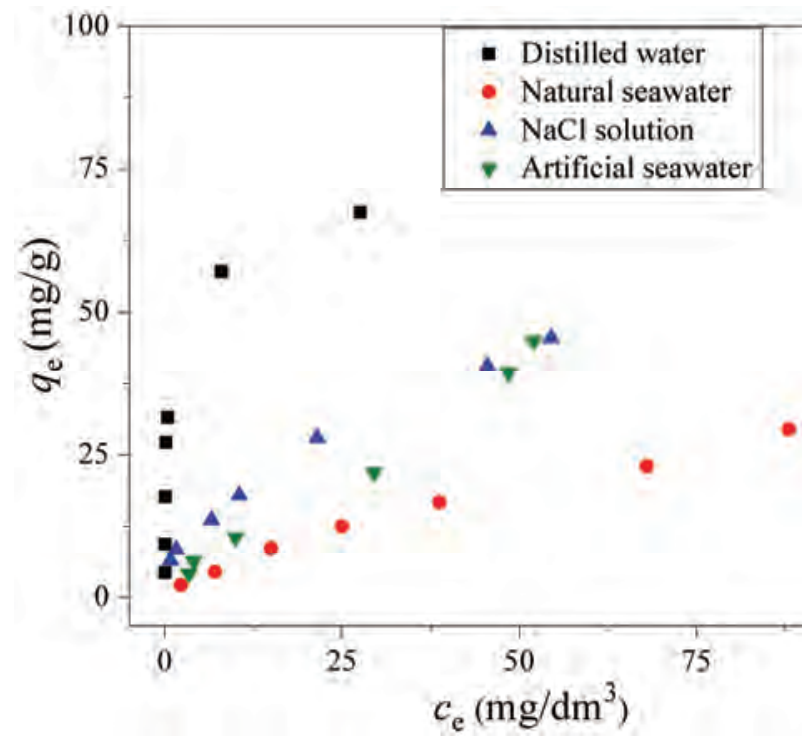

Figure 2. The comparison of sorption isotherms for $\mathrm{Cd}^{2+}$ on $\mathrm{Fe}(\mathrm{III})$-zeolite from different types of water at initial $\mathrm{pH} 7$.

The final pHs of the solutions in distilled water were between 8.98 (for $c_{\mathrm{i}}=5 \mathrm{mg} / \mathrm{dm}^{3}$ ) and 7.02 (for $c_{\mathrm{i}}=100$ $\mathrm{mg} / \mathrm{dm}^{3}$ ), which indicates that the specific sorption increased with $c_{i}$ increase. In the case of $\mathrm{NaCl}$ solutions, $\mathrm{pH}_{\mathrm{f}}$ was between 8.70 and 7.43. Lower $\mathrm{pH}_{\mathrm{f}}$ for $c_{\mathrm{i}}=5$ $\mathrm{mg} / \mathrm{dm}^{3}$ than for solution in distilled water can be explained by the specific sorption of $\mathrm{Na}^{+}$on the sorbent surface. $\mathrm{Na}^{+}$are generally indifferent ions, which mean that they can not be specifically sorbed, but that is possible when the concentration is very high. Higher $\mathrm{pH}_{\mathrm{f}}$ in $\mathrm{NaCl}$ solution for $c_{\mathrm{i}}=100 \mathrm{mg} / \mathrm{dm}^{3}$ than in the same solution in distilled water indicates lower specific sorption. Thus, the specific sorption is less pronounced in $\mathrm{NaCl}$ solution than in distilled water. The effect of ions in artificial seawater on the specific sorption is even more pronounced, because the $\mathrm{pH}_{\mathrm{f}}$ changed from 7.89 to 7.48. Higher valence ions in artificial seawater can be specifically sorbed more than $\mathrm{Na}^{+}$, so $\mathrm{pH}_{\mathrm{f}}$ for $c_{\mathrm{i}}=$ $=5 \mathrm{mg} / \mathrm{dm}^{3}$ was much lower than in $\mathrm{NaCl}$ solution and distilled water. The final $\mathrm{pHs}$ in natural seawater were approximately 7.8 for all concentration, due to the buffering effect as a result of the presence of bicarbonates.

By comparing the sorption isotherms (Fig. 2) it is obvious that the order of sorption capacity of $\mathrm{Fe}$ (III)-zeolite for $\mathrm{Cd}^{2+}$, at initial $\mathrm{pH} 7$ is: distilled water $>\mathrm{NaCl}$ solution $>$ artificial seawater $>$ natural seawater. This order is the same as in the investigation of the effect of the initial $\mathrm{pH}$ value on $\mathrm{Cd}^{2+}$ sorption. 


\section{Isotherms modeling}

The sorption equilibrium data were analyzed by linear form of the Langmuir and Freundlich models.

The Langmuir isotherm model assumes monolayer sorption, where the energy of sorption for each sorbate species is the same and independent of surface coverage. The sorption occurs only on localized sites and involves no interactions between sorbed species [16,24-28].

The Freundlich isotherm model describes sorption on heterogeneous surfaces where sorption sites have different energies of sorption. This empirical model can be applied to multilayer sorption, which can include chemisorption (if active sites are strong enough) followed by physisorption [17,24-28].

The corresponding Langmuir and Freundlich parameters for $\mathrm{Cd}^{2+}$ sorption onto $\mathrm{Fe}(\mathrm{III})$-zeolite from different types of water are given in Table 2. The correlation coefficient values indicate the superiority of Langmuir over Freundlich model for the sorption from distilled water, while Freundlich model is better for modeling of the sorption from saline waters. According to this, it can be concluded that ions from saline waters influence not only sorption capacity, but also cause change of sorption mechanism. The sorbent surface was homogeneous during the sorption from distilled water and the sorption took place until monolayer was formed, while in the case of the sorption from saline waters, sorbent surface was heterogeneous and more than one layer of $\mathrm{Cd}^{2+}$ were formed.

The feasibility of $\mathrm{Cd}^{2+}$ sorption from distilled water in the investigated concentration range can be expressed in terms of a dimensionless constant $R_{\mathrm{L}}$ (Eq. (8)), called the constant separation factor or equilibrium parameter [24,25,27]:

$$
\mathrm{R}_{\mathrm{L}}=\frac{1}{1+k_{\mathrm{L}} c_{\mathrm{i}}}
$$

where $k_{\mathrm{L}}$ is the Langmuir constant $\left(\mathrm{dm}^{3} / \mathrm{mg}\right)$, and $c_{\mathrm{i}}$ is the initial concentration $\left(\mathrm{mg} / \mathrm{dm}^{3}\right)$. According to the value of $R_{L}$ it is possible to assess irreversibility of the sorption process: as the value of $R_{L}$ closer to zero, the process is more irreversible. When the value of $k_{\mathrm{L}}$ is infinitely large, which means that the bond between a sorbent and a sorbate is infinitely strong, the sorption process is irreversible $\left(R_{\mathrm{L}}=0\right)$. The dependence of $R_{\mathrm{L}}$ on $c_{i}$ in the investigated range of $\mathrm{Cd}^{2+}$ concentration in distilled water is presented in Fig. 3. It can be seen that $R_{\mathrm{L}}$ for the $\mathrm{Cd}^{2+}$ sorption from distilled water has very low values, which indicate favorable sorption and high degree of irreversibility.

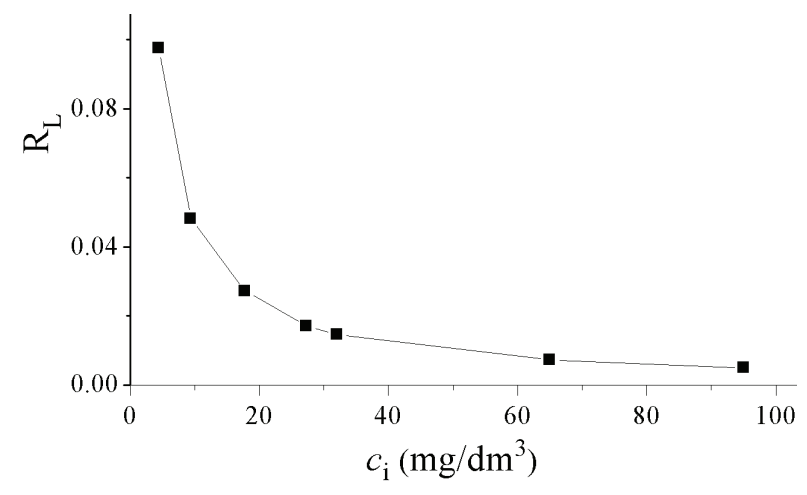

Figure 3. The dependence of $R_{L}$ on the initail $\mathrm{Cd}^{2+}$ concentration.

In the case of the sorption from saline water, the Freundlich constant $k_{\mathrm{F}}$ had the lowest value for the seawater, slightly larger for the artificial seawater and the largest for the $\mathrm{NaCl}$ solution, meaning that the sorption capacity of $\mathrm{Fe}(\mathrm{III})$-zeolite decreased in the following order: $\mathrm{NaCl}$ solution > artificial seawater > $>$ natural seawater. These results are in accordance with the conclusions made from studying the influence of $\mathrm{pH}_{\mathrm{i}}$ value on sorption capacity and according to sorption isotherms obtained for different types of water.

The Freundlich parameter $n$ is a sorption intensity parameter, where the strength of sorption bonds is higher when $n$ is higher. In that way, the value of $n$ is an indication of the favorability of adsorption. Values of $n$ $>1$ represent favorable nature of adsorption [24-28]. According to the values of $n$ for $\mathrm{Cd}^{2+}$ sorption from saline water (Table 2) it can be concluded that the sorption was a favorable process and that bonds between $\mathrm{Cd}^{2+}$ and Fe-zeolite surface were stronger in $\mathrm{NaCl}$ solution than in natural and artificial seawater. Obviously, the presence of higher-valence ions in seawaters, such as $\mathrm{Ca}^{2+}$ and $\mathrm{Mg}^{2+}$ influenced the strength of bonds between $\mathrm{Cd}^{2+}$ and the surface sites on the adsorbent.

Table 2. The Langmuir and Freundlich parameters and the correlation coefficients for $\mathrm{Cd}^{2+}$ sorption onto Fe(III)-zeolite from different types of water

\begin{tabular}{lccccccc}
\hline Type of water & \multicolumn{3}{c}{ Langmuir parameters } & & \multicolumn{3}{c}{ Freundlich parameters } \\
\cline { 2 - 4 } & $q_{\mathrm{m}} / \mathrm{mg} \mathrm{g}^{-1}$ & $k_{\mathrm{L}} / \mathrm{dm}^{3} \mathrm{mg}^{-1}$ & $R^{2}$ & & $k_{\mathrm{F}} /\left((\mathrm{mg} / \mathrm{g})\left(\mathrm{mg} / \mathrm{dm}^{3}\right)^{n}\right)$ & $1 / n$ & $R^{2}$ \\
\hline Distilled water & 68.027 & 2.10 & 0.997 & & 4.328 & 0.335 & 0.767 \\
Natural seawater & 43.478 & 0.017 & 0.864 & & 1.090 & 0.702 & 0.993 \\
NaCl solution & 53.763 & 0.071 & 0.912 & & 2.268 & 0.466 & 0.984 \\
Artificial seawater & 9.091 & 0.122 & 0.127 & & 1.305 & 0.744 & 0.919 \\
\hline
\end{tabular}




\section{Effect of contact time}

The effect of contact time on $\mathrm{Cd}^{2+}$ sorption onto $\mathrm{Fe}(\mathrm{III})$-zeolite from different types of water is presented in Fig 4. As it was expected, the extent of $\mathrm{Cd}^{2+}$ removal increased with the contact time. The $\mathrm{Cd}^{2+}$ uptake was rapid at the beginning, then was slow in the case of the sorption from distilled water, $\mathrm{NaCl}$ solution, and artificial seawater, while the sorption from seawater was slow at the beginning, and then increased. Such difference in time-dependence of sorption from seawater and other types of water can be explained by the presence of some organic compounds in natural seawater which can influence the rate of sorption.

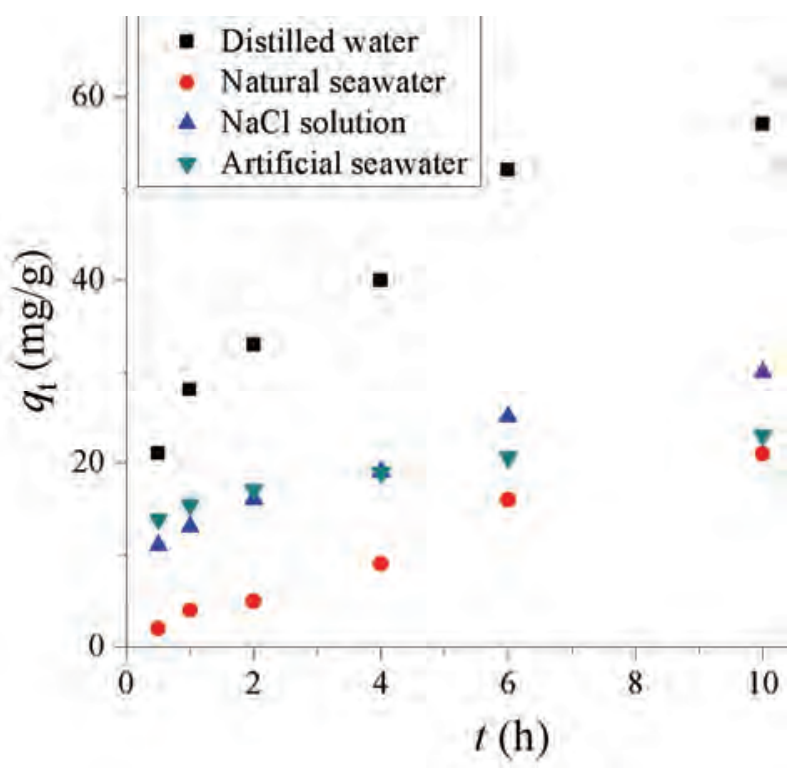

Figure 4. The effect of contact time on the $\mathrm{Cd}^{2+}$ sorption onto $\mathrm{Fe}(I I I)-z e o l i t e$ from different types of water. Concentration of $\mathrm{Cd}^{2+}$ solution was $100 \mathrm{mg} / \mathrm{dm}^{3}$.

\section{Kinetics models}

The sorption kinetics data were analyzed by three, most widely used kinetics models, i.e., the pseudo-first order, pseudo-second order, and intra-particle diffusion models. The kinetic constants and correlation coefficients of these models are given in Table 3 .

The pseudo-first order model is based on the assumption that the sorption rate is proportional to the number of free sites, while in the case of the pseudo- -second-order kinetic model, the rate of sorption is proportional to the square of the number of unoccupied sites. According to the values of correlation coefficients (Table 3), it can be seen that pseudo-first order model can be applied for all the types of water, but for distilled water a slightly higher correlation coefficient was obtained for the pseudo second order model. In addition, pseudo-second-order model fits well the kinetics data of the $\mathrm{Cd}^{2+}$ adsorption from $\mathrm{NaCl}$ solution and artificial seawater, while in the case of natural seawater the correlation coefficient is very low. In that way, kinetics analysis showed that the mechanism of Cd(II) sorption from natural seawater differs from the sorption mechanism out of distilled water, $\mathrm{NaCl}$ solution and artificial seawater.

Sorption of any metal ion from aqueous phase onto porous materials proceeds by a multi-step process, and the rate of the sorption is controlled by either the film diffusion (external mass transfer) or the intra-particle diffusion rate or both $[24,25,29-32]$. In order to identify the diffusion mechanism, the intra-particle diffusion model (Eq. (7)) was applied and dependences $q_{\mathrm{t}}$ versus $t^{0.5}$ for all types of water are presented in Fig. 5 . All the dependences consisted of two linear portions, indicating that the two stages occurred during sorption. The first portion is attributed to the boundary layer diffusion and the second one to the region where the intra-particle diffusion is involved in the sorption process [24,25,29-32]. Figure 5 shows differences between natural seawater and other types of water: the first linear part is longer for natural seawater than for other types of water, which means that boundary layer diffusion was included in sorption from seawater more than from other types of water. It can be supposed that some components from natural seawater, for example organic components, sorb at the surface of the sorbent, block some active sites at the outer surface of the sorbent and increase boundary layer.

The values of intra-particle diffusion rate constant, $k_{\mathrm{td}}$, calculated from the second linear part of the dependence $q_{\mathrm{t}}$ versus $t^{0.5}$ (Fig. 5) are presented in Table 3 . The highest value of $k_{\mathrm{td}}$ was obtained for distilled water, probably because there are no other dissolved substances that could slow down the $\mathrm{Cd}^{2+}$ diffusion in the pores.

Table 3. The kinetic parameters and correlation coefficients for the $\mathrm{Cd}^{2+}$ sorption onto $\mathrm{Fe}(\mathrm{III})$-zeolite from different types of water

\begin{tabular}{|c|c|c|c|c|c|c|c|}
\hline \multirow[t]{2}{*}{ Type of water } & \multicolumn{2}{|c|}{ Pseudo-first order constants } & \multicolumn{3}{|c|}{ Pseudo-second order constants } & \multicolumn{2}{|c|}{ Intra-particle diffusion model constants } \\
\hline & $k_{1} \times 10^{3} / \mathrm{min}^{-1}$ & $R^{2}$ & $q_{\mathrm{e}} / \mathrm{mg} \mathrm{g}^{-1}$ & $k_{2} / \mathrm{g} \mathrm{mg}^{-1} \cdot \min ^{-1}$ & $R^{2}$ & $k_{\mathrm{td}} / \mathrm{g} \mathrm{mg}^{-1} \mathrm{~min}^{-0.5}$ & $R^{2}$ \\
\hline Distilled water & 4.61 & 0.90 & 64.27 & $1.67 \cdot 10^{-4}$ & 0.98 & 1.82 & 0.96 \\
\hline Seawater & 3.90 & 0.96 & 47.62 & $2.59 \cdot 10^{-5}$ & 0.52 & 1.29 & 0.90 \\
\hline $\mathrm{NaCl}$ solution & 3.68 & 0.93 & 33.33 & $2.67 \cdot 10^{-4}$ & 0.95 & 1.01 & 0.98 \\
\hline $\begin{array}{l}\text { Artificial } \\
\text { seawater }\end{array}$ & 3.23 & 0.99 & 23.92 & $1.01 \cdot 10^{-3}$ & 0.99 & 0.50 & 0.99 \\
\hline
\end{tabular}




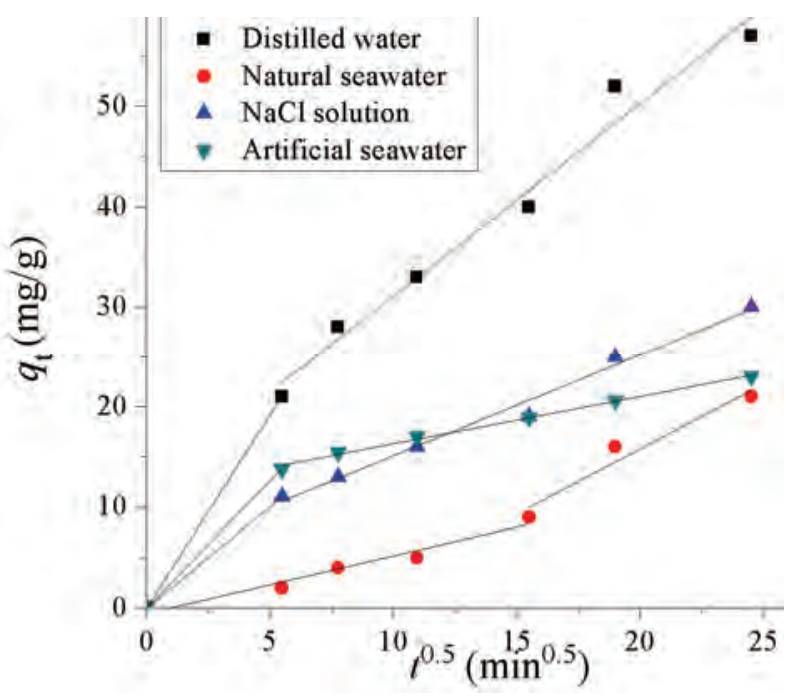

Figure 5. Weber-Morris intraparticle diffusion model plot for the $\mathrm{Cd}^{2+}$ sorption onto $\mathrm{Fe}(\mathrm{III})$-zeolite from different types of water.

\section{CONCLUSIONS}

The sorption potential of zeolite modified by iron(III) oxide to cadmium ions from different types of water was evaluated. It was shown that the sorbent capacity and sorption mechanisms are highly influenced by the presence of competitive ions in water. The sorbent capacity at initial $\mathrm{pH} 7$ decreased in the following order: distilled water $>\mathrm{NaCl}$ solution $>$ artificial seawater $>$ natural seawater. The Freundlich isotherm model provides the best fit to the sorption equilibrium data obtained from saline waters, which indicates heterogeneity of the sorbent surface and the multilayer adsorption. The sorption was a favorable process and bonds between cadmium ions and Fe(III)-zeolite surface were stronger in $\mathrm{NaCl}$ solution than in natural and artificial seawater. In the case of sorption from distilled water, the sorption equilibrium data were best fitted by the Langmuir model, indicating homogeneous and monolayer sorption. Kinetics analysis showed that both boundary layer diffusion and intra-particle diffusion influenced the rate of the sorption from all types of water. In the case of the sorption from natural seawater, the intraparticle diffusion was significant at longer contact times than in the case of other types of water.

\section{Acknowledgements}

The authors would like to acknowledge the financial support of the Ministry of Education, Science and Technological Development of the Republic of Serbia, Project No. III 45019.

\section{REFERENCES}

[1] K. S. Low, C. K. Lee, S. C. Liew, Sorption of cadmium and lead from aqueous solutions by spent Grain, Process Biochem. 36 (2000) 59-64.

[2] J. Hizal, R. Apak, Modeling of cadmium(II) adsorption on kaolinite-based clays in the absence and presence of humic acid, Appl. Clay Sci. 32 (2006) 232-244.

[3] H.K. Boparai, M. Joseph, D.M. O'Carroll, Kinetics and thermodynamics of cadmium ion removal by adsorption onto nano zerovalent iron particles, J. Hazard. Mater. 186 (2011) 458-465.

[4] E. Gutiérrez-Segura, M. Solache-Ríos, A. Colín-Cruz, C. Fall, Adsorption of cadmium by $\mathrm{Na}$ and Fe modified zeolitic tuffs and carbonaceous material from pyrolyzed sewage sludge, J. Environ. Manage. 97 (2012) 6-13.

[5] M. Ahmad, A.R.A. Usman, S.S. Lee, S. Kim, J. Joo, J.E. Yang, Y.S Ok, Eggshell and coral wastes as low cost sorbents for the removal of $\mathrm{Pb}^{2+}, \mathrm{Cd}^{2+}$ and $\mathrm{Cu}^{2+}$ from aqueous solutions, J. Ind. Eng. Chem. 8 (2012) 198-204.

[6] R. Schmuhl, HM. Krieg, K. Keizer, Adsorption of $\mathrm{Cu}(\mathrm{II})$ and $\mathrm{Cr}(\mathrm{VI})$ ions by chitosan: Kinetics and equilibrium studies, Water SA 27 (2001) 1-7.

[7] G. Crini, Recent developments in polysaccharide-based materials used as adsorbents in wastewater treatment, Prog. Polym. Sci. 30 (2005) 38-70.

[8] F. Fu, Q. Wang, Removal of heavy metal ions from wastewaters: A review, J. Environ. Manage. 92 (2011) 407-418.

[9] S. Wang, Y. Peng, Natural zeolites as effective adsorbents in water and wastewater treatment, Chem. Eng. J. 156 (2010) 11-24.

[10] A. Dimirkou, Uptake of $\mathrm{Zn}^{2+}$ by a fully iron-exchanged clinoptilolite, Case study of heavily contaminated drinking water samples. Water Res. 41 (2007) 2763-2773.

[11] M. Doula, Synthesis of a clinoptilolite-Fe system with high Cu sorption capacity, Chemosphere 67 (2007) 731-740 .

[12] M.K. Doula, A. Dimirkou, Use of an iron-overexchanged clinoptilolite for the removal of $\mathrm{Cu}^{2+}$ from heavily contaminated drinking water samples, J. Hazard. Mater. 151 (2008) 738-745.

[13] M.K. Doula, Simultaneous removal of $\mathrm{Cu}, \mathrm{Mn}$ and $\mathrm{Zn}$ from drinking water with the use of clinoptilolite and its Fe-modified form, Water Res. 43 (2009) 3659-3672.

[14] M.T. Mihajlović, S.S. Lazarević, I.M. Janković-Častvan, B. M. Jokić, Đ.T. Janaćković, R.D. Petrović, A comparative study of the removal of lead, cadmium and zinc ions from aqueous solutions by and Fe(III)-modified zeolite, Chem. Ind. Chem. Eng. Q. 21 (2015) 295-303.

[15] P.J. Ramírez, G. Mul, F. Kapteijn, J.A. Moulijn, A.R. Overweg, J.A. Doménech, A. Ribera, I.W.C.E. Arends, Physicochemical characterization of isomorphously substituted FeZSM-5 during activation, J. Catal. 207 (2002) 113-126.

[16] I. Langmuir, The adsorption of gases on plane surfaces of glass, mica and platinum, J. Am. Chem. Soc. 40 (1918) 1361-1403. 
[17] H. Freundlich, Concerning adsorption in solutions. Zeitschrift für Physikalische Chemie. 57 (1906) 385-470.

[18] S. Lagergren, Zur theorie der sogenannten adsorption gelöester stoffe, Kungliga Svenska Vetenskapsakademiens Handlingar. 24 (1898) 1-39.

[19] Y.S. Ho, G. McKay, Sorption of dye from aqueous solution by peat, Chem. Eng. J. 70 (1998) 115-124.

[20] G. McKay, Y.S. Ho, Pseudo-second order model for sorption processes, Process Biochem. 34 (1999) 451465.

[21] W.J. Weber, J.C. Morris, Kinetics of adsorption on carbon from solution, J. Sanit. Eng. Div. Am. Soc. Civil Eng. 89 (1963) 31-60.

[22] M.N. Rahaman, Ceramic Processing and Sintering, Second Edition, Marcel Dekker Inc., New York, 2003.

[23] J.C. Crittenden, R.R. Trussell, D.W. Hand, K.J. Howe, G. Tchobanoglous, Water Treatment: Principles and Design, John Wiley \& Sons. Inc., Hoboken, NJ, 2005.

[24] C. Luo, Z. Tian, B. Yang, L. Zhang, S. Yan, Manganese dioxide/iron oxide/acid oxidized multi-walled carbon nanotube magnetic nanocomposite for enhanced hexavalent chromium removal, Chem. Eng. J. 234 (2013) 256-265.

[25] E.S. Dragan, D.F.A. Loghin, Enhanced sorption of methylene blue from aqueous solutions by semi-IPN composite cryogels with anionically modified potato starch entrapped in PAAm matrix, Chem. Eng. J. 234 (2013) 211-222.
[26] X. Wang, R. Sun, C. Wang, pH dependence and thermodynamics of $\mathrm{Hg}(\mathrm{II})$ adsorption ontochitosan-poly(vinyl alcohol) hydrogel adsorbent, Colloids Surfaces, A 441 (2014) 51-58.

[27] M. Naushad, Surfactant assisted nano-composite cation exchanger: Development, characterization and applications for the removal of toxic $\mathrm{Pb}^{2+}$ from aqueous medium, Chem. Eng. J. 235 (2014) 100-108.

[28] O.S. Ayanda, O.S. Fatoki, F.A. Adekola, B.J. Ximba, Removal of tributyltin from shipyard process wastewater by fly ash, activated carbon and fly ash/activated carbon composite: adsorption models and kinetics, J. Chem. Technol. Biotechnol. 88 (2013) 2201-2208.

[29] M.V. Dinu, E.S. Dragan, Evaluation of $\mathrm{Cu}^{2+}, \mathrm{Co}^{2+}$ and $\mathrm{Ni}^{2+}$ ions removal from aqueous solution using a novel chitosan/clinoptilolite composite: Kinetics and isotherms, Chem. Eng J. 160 (2010) 157-163.

[30] A.K. Bhattacharya, T.K. Naiya, S.N. Mandal, S.K. Das, Adsorption, kinetics and equilibrium studies on removal of $\mathrm{Cr}(\mathrm{VI})$ from aqueous solutions using different lowcost adsorbents, Chem. Eng J. 137 (2008) 529-541.

[31] M. Nasiri Sarvi, T.B. Bee, C.K. Gooi, B.W. Woonton, M.L. Gee, A.J. O'Connor, Development of functionalized mesoporous silica for adsorption and separation of dairy proteins, Chem. Eng J. 235 (2014) 244-251.

[32] M.C.S. Faria, R.S. Rosemberg, C.A. Bomfeti, D.S. Monteiro, F. Barbosa, L.C.A. Oliveira, M. Rodriguez, M.C. Pereira, J.L. Rodrigues, Arsenic removal from contaminated water by ultrafine $\mathrm{d}-\mathrm{FeOOH}$ adsorbents, Chem. Eng J. 237 (2014) 47-54.

\title{
IZVOD
}

\section{SORPCIJA JONA KADMIJUMA IZ SLANIH VODA NA Fe(III)-ZEOLITU}

\author{
Aysha Ali Ahribesh ${ }^{1}$, Slavica Lazarević ${ }^{1}$, Branislav Potkonjak ${ }^{2}$, Andjelika Bjelajac ${ }^{3}$, Djordje Janaćković ${ }^{1}$, Rada Petrović $^{1}$ \\ ${ }^{1}$ Tehnološko-metalurški fakultet, Univerzitet u Beogradu, Karnegijeva 4, Beograd, Srbija \\ ${ }^{2}$ Institut za hemiju, tehnologiju i metalurgiju, Univerzitet u Beogradu, Njegoševa 12, Beograd, Srbija \\ ${ }^{3}$ Inovacioni centar Tehnološko-metalurškog fakulteta, Univerzitet u Beogradu, Beograd, Srbija \\ (Naučni rad)
}

$\mathrm{U}$ ovom radu je ispitivana sorpcija $\mathrm{Cd}^{2+}$ iz prirodne morske vode, laboratorijski pripremljene morske vode, destilovane vode i rastvora $\mathrm{NaCl}$, iste jonske jačine kao morska voda, na zeolitu modifikovanom gvožđe(III)-oksidom. Pokazano je da sorpcija zavisi od vremena, početne koncentracije $\mathrm{Cd}^{2+} \mathrm{i} \mathrm{pH}$ vrednosti. Sorpcioni kapacitet Fe(III)-zeolita za $\mathrm{Cd}^{2+}$ pri početnoj pH 7 opada u sledećem nizu: destilovana voda $>\mathrm{NaCl}$ rastvor > laboratorijski pripremljena morska voda > prirodna morska voda. Modelovanje rezultata ispitivanja sorpcije u ravnotežnim uslovima je pokazalo da se adsorpcija iz destilovane vode može opisati Langmirovim modelom, što ukazuje na homogenu sorpciju i formiranje monosloja na površini $\mathrm{Fe}(I I I)-z e o l i t a$. Rezultati sorpcije iz slanih voda se bolje opisuju Frojndlihovim nego Langmirovim modelom, što ukazuje na višeslojnu sorpciju na heterogenoj površini sorbenta. Vrednosti Frojndlihovog parametra $n$ pokazuju da je sorpcija $\mathrm{Cd}^{2+}$ na $\mathrm{Fe}(\mathrm{III})$-zeolitu favorizovan proces i da su veze između $\mathrm{Cd}^{2+}$ i površine $\mathrm{Fe}(\mathrm{III})$-zeolita jače u $\mathrm{NaCl}$ rastvoru nego u prirodnoj i laboratorijski pripremljenoj morskoj vodi. Kinetička analiza sorpcije je pokazala da se mehanizam sorpcije iz prirodne morske vode razlikuje od mehanizma sorpcije iz ostalih ispitivanih tipova vode. Kinetički model unutarčestične difuzije je pokazao da i difuzija kroz granični sloj i unutarčestična difuzija određuju brzinu sorpcije. Difuzija kroz granični sloj je u većoj meri zastupljena kod sorpcije iz morske vode nego u slučaju sorpcije iz drugih ispitivanih tipova vode.
Ključne reči: Sorpcija • Kadmijum jon • Fe(III)-zeolit • Morska voda • Modelovanje 